\title{
Chromogranin A is a reliable serum diagnostic biomarker for pancreatic neuroendocrine tumors but not for insulinomas
}

\author{
Xin-Wei Qiao ${ }^{1 \dagger}$, Ling Qiu ${ }^{2 \dagger}$, Yuan-Jia Chen ${ }^{1,3^{*}}$, Chang-Ting Meng ${ }^{4}$, Zhao Sun ${ }^{4}$, Chun-Mei Bai ${ }^{4}$, Da-Chun Zhao ${ }^{5}$, \\ Tai-Ping Zhang ${ }^{6}$, Yu-Pei Zhao ${ }^{3,6}$, Yu-Li Song ${ }^{1}$, Yu-Hong Wang ${ }^{7}$, Jie Chen ${ }^{7}$ and Chong-Mei Lu ${ }^{1}$
}

\begin{abstract}
Background: Pancreatic neuroendocrine tumors (PNETs) are a group of rare tumors. Chromogranin A (CgA) was considered as the most practical and useful serum tumor marker in PNET patients. But peripheral blood levels of $\mathrm{CgA}$ are not routinely tested in Chinese patients with PNETs. This study was to assess the diagnostic value of CgA in Chinese patients with PNETs especially in patients with insulinomas.

Methods: Eighty-nine patients with PNETs including 57 insulinomas and 32 non-insulinoma PNETs as well as 86 healthy participants were enrolled in this study between September 2003 and June 2013. Serum levels of $\mathrm{CgA}$ were measured by ELISA method. Expression of CgA protein was detected in 26 PNET tissues including 14 insulinomas by immunohistochemical staining.

Results: Serum levels of CgA in 89 PNET patients were significantly higher than that in healthy controls $\left(P=7.2 \times 10^{-9}\right)$. Serum levels of $\mathrm{CgA}$ in 57 patients with insulinomas (median $64.8 \mathrm{ng} / \mathrm{ml}$, range 25-164) were slightly higher than the levels in healthy controls (median $53.4 \mathrm{ng} / \mathrm{ml}$, range 39-94) but much lower than the levels in 32 patients with non-insulinoma PNETs (median $193 \mathrm{ng} / \mathrm{ml}$, range 27-9021), $P=0.001$. The serum CgA levels were reduced in 16 of 17 patients with insulinomas after tumor resection. ROC curve showed that $\mathrm{CgA}$ values at $60 \mathrm{ng} / \mathrm{ml}$ distinguished patients with insulinomas from healthy controls but its sensitivity and specificity were $66.7 \%$ and $73.3 \%$, respectively. In contrast, $\mathrm{CgA}$ values at $74 \mathrm{ng} / \mathrm{ml}$ distinguished patients with non-insulinoma PNETs from healthy controls, and the sensitivity and specificity were $65.6 \%$ and $91.9 \%$, respectively. Except for two insulinomas with negative staining of $\mathrm{CgA}, 12$ insulinoma tissues showed positive staining of $\mathrm{CgA}$.

Conclusion: $\mathrm{CgA}$ is a reliable serum diagnostic biomarker for PNETs but not for insulinomas.
\end{abstract}

\section{Background}

Pancreatic neuroendocrine tumors (PNETs) are a group of rare tumors. The prevalence and incidence have increased over the past 3 decades [1-5]. The clinical presentations of PNETs are very complicated due to excess of gut peptides produced by functioning PNETs while

\footnotetext{
*Correspondence: yuanjchen@163.com

${ }^{\dagger}$ Equal contributors

'Department of Gastroenterology, Peking Union Medical College Hospital, Peking Union Medical College, Chinese Academy of Medical Sciences, Beijing 100730, People's Republic of China

${ }^{3}$ Key Laboratory of Endocrinology (Ministry of Health), Department of Endocrinology, Peking Union Medical College Hospital, Peking Union Medical College, Chinese Academy of Medical Sciences, Beijing 100730, People's Republic of China

Full list of author information is available at the end of the article
}

symptoms of nonfunctioning PNETs (NF) are obscure $[1,3]$. In addition, most of PNETs could be biologically aggressive $[1,3,6]$. Thus, the earlier and accurate diagnosis of PNET is important to facilitate surgical resection and/ or to initiate appropriate medical management such as molecular targeted therapy, biotherapy and other intensive care.

Chromogranin A (CgA) is a 46-kDa glycoprotein, member of the granin family, exists within all type of neurons, normal neuroendocrine cells and is expressed in NET cells $[7,8]$. Over the past 2 decades, many studies reported and confirmed that $\mathrm{CgA}$ was a reliable diagnostic biomarker for NETs including gastroentero-pancreatic NETs (GEP-NET) [1,3,5-20] and also might be a prognostic biomarker for NETs [21]. Moreover, several studies showed that 
peripheral blood levels of $\mathrm{CgA}$ were increased in endocrine-associated tumors, for example, breast cancer [22] and prostate cancer [23,24]. Recently, elevated serum/ plasma levels of CgA were found in a number of nonendocrine solid tumors, such as hepatic carcinomas [25,26] and pancreatic cancer [27]. Examination of CgA levels could be used not only for diagnosis but also for prognostic evaluation in these tumors [21,23,25,27].

In recent ENETS and NANETS consensus guidelines, CgA was considered as the most practical and useful serum tumor marker in PNET patients [28,29]. Some studies suggested that testing blood CgA should be mandatory for NET diagnosis [7]. However, few attention has been paid to the insulinoma which is the most common type of functioning PNETs [7,8,14,15,17,19,21,30-32]. In addition, peripheral blood levels of $\mathrm{CgA}$ are not routinely tested in Chinese patients with GEP-NET. Using CgA for clinical diagnosis has not been officially approved by Sino Food Drug Administration (SFDA) because little data have been reported.

Thus, the present study is to verify the utility of CgA in diagnosis of PNETs, focusing on its diagnostic value in insulinoma. We found that serum levels of CgA were not significantly elevated in patients with insulinomas, compared to the higher levels of CgA in other PNETs. This finding was rarely reported in previous studies.

\section{Methods}

\section{Ethics statement}

This study was approved by the Scientific Ethics Committee of Peking Union Medical College Hospital and the First Affiliated Hospital of Sun Yat-sen University. Participants provided their written informed consent to participate in this study. The Scientific Ethics Committee of both hospitals approved the consent procedure.

\section{Patients and samples collection}

Eighty-nine Chinese patients with PNETs including 57 insulinomas (one with extensive hepatic metastases), and 32 non-insulinoma PNETs (8 gastrinomas, 4 glucagonomas, 1 VIPoma and $19 \mathrm{NF)}$ as well as 86 healthy participants were enrolled in this study at Peking Union Medical College Hospital and the First Affiliated Hospital of Sun Yat-sen University, between September 2003 and June 2013. The diagnostic criteria for PNETs were reported previously [33-39]. Briefly, the tumors were mainly localized by computed tomography with contrast, magnetic resonance imaging, endoscopic ultrasound and somatostatin receptor scintigraphy. All patients did not suffer with inflammatory diseases (such as inflammatory bowel disease, chronic atrophic gastritis), and the renal, hepatic or cardiac insufficiency was excluded. The patients did not take proton pump inhibitors (PPIs) or histamine 2 receptor blockers as well as somatostatin analogues. The pathological diagnosis was made by 2 experienced pathologists. We analyzed tumor grade in 54 tumors according to ENETS-WHO guideline [40] and analyzed stage in 84 patients according to the ENETS guideline [40].

Before surgery or treatment, blood samples were obtained in 89 fasted patients with PNETs. In 17 patients with insulinomas, blood samples were postoperatively collected during 3rd to 7th days after resection. The blood samples from 86 healthy participants (median age 43 years, 38 male) were collected after overnight fasting. Serum were isolated and stored in $-80^{\circ} \mathrm{C}$.

\section{Detecting of serum levels of $\mathrm{CgA}$}

Serum levels of CgA of patients with PNETs and healthy controls were measured by ELISA method with a commercial kit (Chromoa assay; CIS Bio International, France), according to the manufacturer's protocol. Most of samples were duplicated tested, and some of samples were checked in another experiment. Ten samples were double examined in two different labs (one in Beijing and another lab in Guangzhou).

\section{Detecting of $\mathrm{CgA}$ expression in tumor tissues}

Expression of $\mathrm{CgA}$ protein was detected in 26 sections of paraffin-embedded PNETs tissues, including 14 insulinomas, 2 gastrinomas and $10 \mathrm{NF}$ as well as their paired pancreatic (duodenal) tissues by immunohistochemical staining (IHC) with anti-CgA (AC-0037, clone EP38, Epitomics, Inc, Burlingame, CA) at a 1:100 dilution. The criteria of semi-quantitative grading of IHC was similar to our previous report $[36,39]$, i.e. $(-)$ means no positive staining in tumor cells; $( \pm)<20 \%$ tumor cells shown positive staining, $(+) \geq 20 \%$ but $<50 \%$ tumor cells shown positive staining; $(++) \geq 50 \%$ but $<75 \%$ tumor cells shown positive staining; $(+++) \geq 75 \%$ tumor cells shown positive staining. We defined $<20 \%$ tumor cells with staining of $\mathrm{CgA}$ as negative staining, i.e. $(-)$ and $( \pm)$.

\section{Statistical analysis}

To verify the diagnostic value of serum $\mathrm{CgA}$, receiver operating characteristic (ROC) curves were plotted, and the area under the curve (AUC) was calculated. SPSS statistics software version 13.0 was used for statistical analysis. Mann-Whitney method was used to compare the CgA levels between each group of patients and healthy controls. Fisher exact test or Chi's test were used to analyze our data. Two-tailed test was used in all of statistic analysis. $P<0.05$ was considered statistically significant.

\section{Results}

\section{Clinicopathological characteristics}

We studied 89 PNET patients, 73 patients underwent curative surgery and 16 patients did not undergo operation. 
All tumors were well differentiated. The clinicopathological characteristics of 89 patients with PNETs and 57 patients with insulinomas were summarized in Table 1.

\section{CgA Serum Levels in PNET Patients and ROC curves}

The median values of CgA levels in 86 healthy controls, 57 patients with insulinomas and 32 patients with non-insulinoma PNETs were $53.4 \mathrm{ng} / \mathrm{ml}$ (range 39.1 - $94.1 \mathrm{ng} / \mathrm{ml}$ ), $64.8 \mathrm{ng} / \mathrm{ml}$ (range $25.0-164.2 \mathrm{ng} / \mathrm{ml}$ ) and $192.5 \mathrm{ng} / \mathrm{ml}$ (range 26.9 - $9020.7 \mathrm{ng} / \mathrm{ml}$ ), respectively (Figure 1). Serum levels of CgA in 89 PNET patients were significantly higher than that in healthy controls $\left(P=7.2 \times 10^{-9}\right)$. Compared with the serum levels of $\mathrm{CgA}$ in the healthy controls, the CgA levels were significantly elevated in 32 patients with non-insulinoma PNETs $\left(P=3.7 \times 10^{-7}\right)$. In contrast, the levels of $\mathrm{CgA}$ in 57 patients with insulinomas were just slightly higher than that in healthy participants (median $64.8 \mathrm{ng} / \mathrm{ml}$ vs. $53.4 \mathrm{ng} / \mathrm{ml}$ ), see Figure 1 . The serum levels of $\mathrm{CgA}$ in patients with insulinomas (median $64.8 \mathrm{ng} / \mathrm{ml}$ ) were significantly lower than that in the patients with non-insulinoma PNETs (median $192.5 \mathrm{ng} / \mathrm{ml}), P=0.001$, Figure 1 .

Although the levels of CgA in patients with insulinomas were not elevated significantly, it was interesting that the serum levels of $\mathrm{CgA}$ were decreased in 16 of 17 patients with insulinomas after tumor resection (Figure 2A, median $64.8 \mathrm{ng} / \mathrm{ml}$ vs. $50.4 \mathrm{ng} / \mathrm{ml}, P=0.003)$. The postoperative levels of $\mathrm{CgA}$ in patients with insulinomas were almost the same as the levels in healthy controls (Figure $2 \mathrm{~B}$, median $50.4 \mathrm{ng} / \mathrm{ml}$ vs. $53.4 \mathrm{ng} / \mathrm{ml}$ ).

ROC curve showed that $\mathrm{CgA}$ values at $60.4 \mathrm{ng} / \mathrm{ml}$ distinguished patients with insulinomas from healthy controls with the sensitivity of $66.7 \%$ and specificity was 73.3\%, AUC was 0.724 (Figure 3A). In contrast, CgA values at $73.9 \mathrm{ng} / \mathrm{ml}$ distinguished patients with noninsulinoma PNETs from healthy controls, with a sensitivity and specificity were $65.6 \%$ and $91.9 \%$, respectively, AUC was 0.805 (Figure 3B). These findings suggested that the serum levels of $\mathrm{CgA}$ in patients with insulinomas were not obviously elevated and $\mathrm{CgA}$ was not a reliable diagnostic biomarker for insulinomas due to the low specificity.

\section{Correlation of $\mathrm{CgA}$ levels with clinicopathological characteristics in patients with PNETs and insulinomas}

We correlated the CgA levels with clinicopathological features in patients with PNETs as well as insulinomas, respectively (Table 2). We found that the serum CgA levels in 18 patients with tumor metastases were significantly higher than that in 65 patients with localized tumors (median value, $549.8 \mathrm{ng} / \mathrm{ml}$ vs. $64.3 \mathrm{ng} / \mathrm{ml}$, respectively, $P=4.1 \times 10^{-5}$ ), see Figure 4 . The serum levels of CgA in PNETs patients were not significantly associated with gender, tumor size and grade but associated with age, primary tumor location and stage, see Table 2. Furthermore, we correlated the CgA levels with clinicopathological features in patients with insulinomas. The serum levels of CgA in patients with insulinomas were not significantly associated with gender, tumor size (Figure 5A), grade and stage, but significantly associated with age (Figure 5B) and primary tumor location (Figure 5C), see Table 2.

\section{The CgA levels in patients with localized insulinomas and in patients with localized non-insulinomas}

Our data above showed that CgA levels in patients with tumor metastases were significantly higher than that in patients with localized tumors and only 1 patient with metastasic insulinoma was included in our study. We compared serum CgA levels in 56 localized insulinoma with the CgA levels in 12 patients with localized noninsulinomas. The serum levels of CgA in both groups of patients were similar, $65.2 \mathrm{ng} / \mathrm{ml}$ vs. $59.4 \mathrm{ng} / \mathrm{ml}, P=0.693$ (Figure 6). As we mentioned above, the ROC curve showed that CgA cut-off values was $60.4 \mathrm{ng} / \mathrm{ml}$ for insulinomas and $73.9 \mathrm{ng} / \mathrm{ml}$ for non-insulinomas, respectively. We noticed that only 3 of 56 patients with localized insulinomas had the CgA levels more than $120.8 \mathrm{ng} / \mathrm{ml}$ (i.e. two fold more than cut-off values for insulinoma), whereas 4 of 12 patients with localized non-insulinomas had CgA levels more than $242 \mathrm{ng} / \mathrm{ml}$ (also two fold more than cutoff values for non-insulinoma), $P=0.015$ (Fisher exact), see Figure 6 , indicating the patients with localized non-insulinomas had a more frequency of remarkable elevation of $\mathrm{CgA}$ than that in the patients with localized insulinomas.

\section{The expression of $\mathrm{CgA}$ in PNETs tissues}

Because the serum CgA levels were not elevated in patients with insulinomas, we wanted to determine whether the protein of CgA was expressed in tumor tissues or not. We observed strong or medium expression of $\mathrm{CgA}$ in 12 of 14 insulinomas as well as in 11 of 12 non-insulinoma PNETs, as detected by IHC (Figure 7). Two of 14 insulinomas and 1 of 12 non-insulinoma PNETs had very weak IHC staining of CgA protein. The expression of CgA in PNET tissues was not associated with serum levels of CgA in corresponding patients. These data suggested that most of insulinoma cells could synthesize a great amount of CgA protein.

\section{Discussion}

Circulating CgA levels have been confirmed to be useful diagnostic marker for NETs, with a high specificity and sensitivity $[1,3,5-19,28]$. In the present study, we verified the diagnostic value of serum $\mathrm{CgA}$ in a series of patients with non-insulinoma PNETs, in agreement with previous studies. The sensitivity and specificity were $65.6 \%$ and $91.9 \%$, respectively, similar to the rate of $67 \%$ and $96 \%$ 
Table 1 Clinicopathological characteristics of PNET patients

\begin{tabular}{|c|c|c|}
\hline \multicolumn{2}{|c|}{ Clinicopathological features of patients with PNETs } & \multirow{2}{*}{$\frac{\text { Number }}{36(40.4)}$} \\
\hline Gender $n=89(\%)$ & Male & \\
\hline & Female & $53(59.6)$ \\
\hline & Male : Female & $1: 1.47$ \\
\hline $\begin{array}{l}\text { Age (years) at diagnosis, } \\
\mathrm{n}=87\end{array}$ & Median (range) & $47(16-74)$ \\
\hline \multirow[t]{6}{*}{ PNET subtype $n=89$ (\%) } & Insulinoma & $57(64.0)$ \\
\hline & Non-insulinoma & $32(36.0)$ \\
\hline & NF & $19(21.3)$ \\
\hline & gastrinoma & $8(9.0)$ \\
\hline & glucagonoma & $4(4.5)$ \\
\hline & VIPoma & $1(1.1)$ \\
\hline \multirow{2}{*}{$\begin{array}{l}\text { Inherited or sporadic PNETs, } \\
\mathrm{n}=89(\%)\end{array}$} & Sporadic & 86 (96.6) \\
\hline & MEN-1 associated & $3(3.4)$ \\
\hline \multirow[t]{2}{*}{ Surgery or not, $n=89(\%)$} & Resection & $73(82.0)$ \\
\hline & Unresection & $16(18.0)$ \\
\hline \multirow{3}{*}{$\begin{array}{l}\text { Primary tumor location, } \\
\mathrm{n}=77(\%)\end{array}$} & Pancreatic head/neck & $40(51.9)$ \\
\hline & Pancreatic body/tail & $36(46.8)$ \\
\hline & duodenum & $1(1.3)$ \\
\hline \multirow{3}{*}{$\begin{array}{l}\text { Tumor size }(\mathrm{cm}) \text { median (range) } \\
\mathrm{n}=82\end{array}$} & & $1.6(0.8-8)$ \\
\hline & Insulinoma $n=56$ & $1.5(0.8-4)$ \\
\hline & Non-insulinoma $n=26$ & $4.3(1.5-8)$ \\
\hline \multirow[t]{2}{*}{ Metastasis or not, $\mathrm{n}=83$ (\%) } & No & $65(78.3)$ \\
\hline & Yes & $18(21.7)$ \\
\hline \multirow[t]{3}{*}{ Grade, $n=54(\%)$} & G1 & $37(68.5)$ \\
\hline & G2 & $15(27.8)$ \\
\hline & G3 & $2(3.7)$ \\
\hline \multirow[t]{4}{*}{ Stage, $\mathrm{n}=84(\%)$} & I & $39(46.4)$ \\
\hline & $\|$ & $22(26.2)$ \\
\hline & III & $5(6.0)$ \\
\hline & IV & $18(21.4)$ \\
\hline
\end{tabular}

Clinicopathological features of patients with Number
insulinomas

\begin{tabular}{lll}
\hline Gender $\mathrm{n}=57$ (\%) & Male & $25(43.9)$ \\
& Female & $32(56.1)$ \\
& Male : Female & $1: 1.28$ \\
Age (years) at diagnosis, $\mathrm{n}=57$ & Median (range) & $47(16-74)$ \\
$\begin{array}{l}\text { Inherited or sporadic PNETs, } \\
\mathrm{n}=57 \text { (\%) }\end{array}$ & Sporadic & $55(96.5)$ \\
& MEN-1 associated & $2(3.5)$ \\
Surgery or not, $\mathrm{n}=57(\%)$ & Resection & $54(94.7)$ \\
& Unresection & $3(5.3)$ \\
Primary tumor location, $\mathrm{n}=56(\%)$ & Pancreatic head/neck & $30(53.6)$ \\
& Pancreatic body/tail & $26(46.4)$
\end{tabular}

Table 1 Clinicopathological characteristics of PNET patients (Continued)

\begin{tabular}{lll}
\hline $\begin{array}{l}\text { Tumor size }(\mathrm{cm}) \text { median (range) } \\
\mathrm{n}=56\end{array}$ & & $1.5(0.8-4)$ \\
Metastasis or not, $\mathrm{n}=57(\%)$ & No & $56(98.2)$ \\
& Yes & $1(1.8)$ \\
Grade, $\mathrm{n}=35(\%)$ & $\mathrm{G} 1$ & $31(88.6)$ \\
& $\mathrm{G} 2$ & $4(11.4)$ \\
\hline
\end{tabular}

when using CIS Bio kits, as Ardill and Erikkson described [12]. Similar to previous studies [9-11,14,16,41,42], we found that $\mathrm{CgA}$ levels in patients with gastrinomas were much higher than those in patients without gastrinsecreting PNETs.

The interesting finding in the study was that serum CgA levels were not elevated in patients with insulinomas, including one patient with extensive liver metastases (48 ng/ml). Most of previous studies on PNETs did not clarify this unusual biochemical feature of insulinoma, the most common subtype of PNETs [7,8,13-16,19,20,31] but Wouter de Herder pointed out in a review that blood levels of CgA were rarely slightly elevated in subjects with insulinomas [43] and Portela-Gomes GM et al. mentioned in a review that well-differentiated NETs expressed CgA epitopes except insulinomas [44]. A recently published guideline which was revised by the UK and Ireland Neuroendocrine Tumor Society and the British Society of Gastroenterology addressed that CgA would not raised in benign insulinomas [45]. Moreover, Nobels et al. studied more than 200 NETs and found that serum CgA levels were rarely slightly elevated in patients with insulinomas

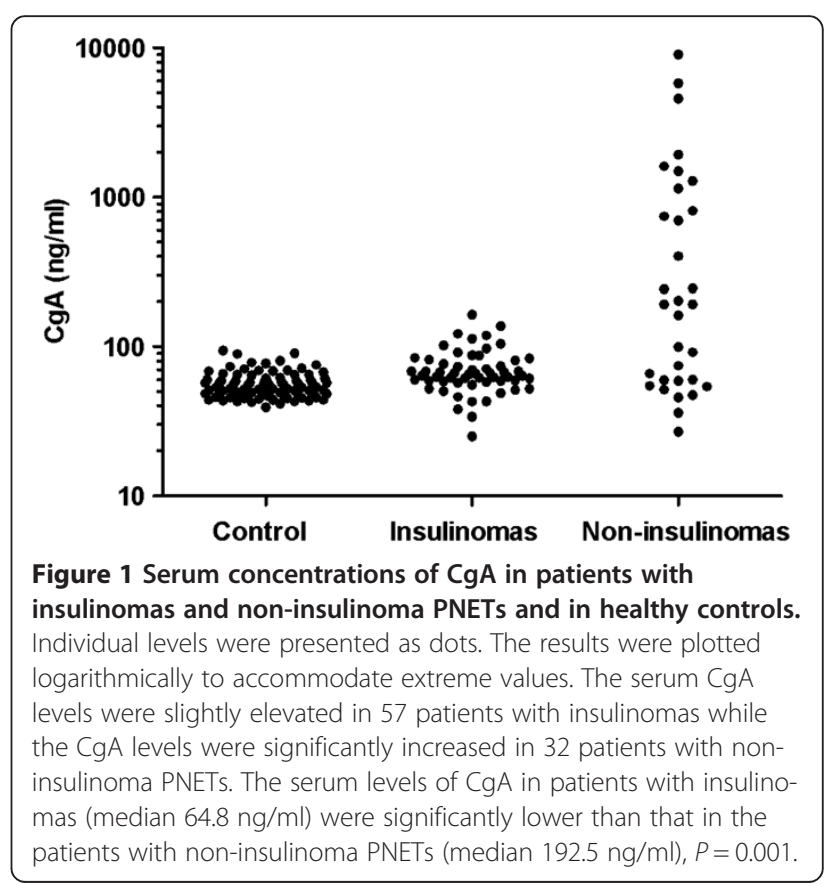



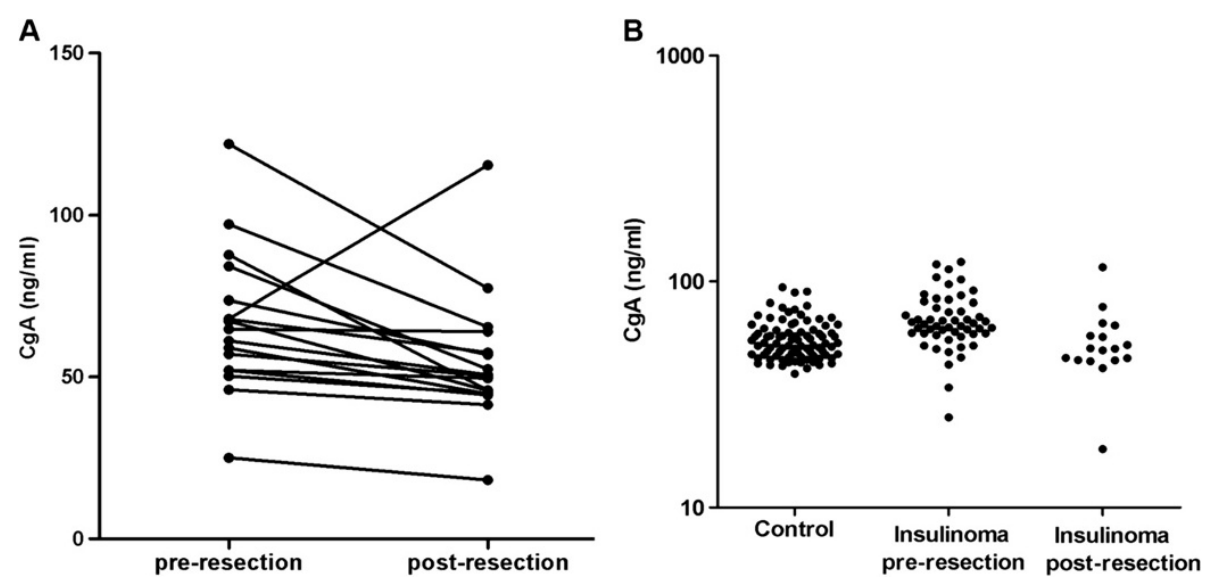

Figure 2 Decreased CgA levels in patients with insulinomas after tumor resection. Figure 2A The serum levels of CgA were significantly reduced in 16 of 17 patients with insulinomas after resection, median $64.8 \mathrm{ng} / \mathrm{ml} \mathrm{vs.} 50.4 \mathrm{ng} / \mathrm{ml}, P=0.003$; Figure $2 \mathbf{B}$ The serum levels of CgA in healthy controls and pre-/post-operative serum levels of $\mathrm{CgA}$ in patients with insulinomas. Individual levels are presented as dots.

(elevated in 2 of 21 patients, range 63-236 ng/ml, upper cut-off value was $220 \mathrm{ng} / \mathrm{ml}$ ) [9]. Another study showed that CgA levels were not elevated in 5 cases of insulinomas [13]. In present study, we focused on insulinomas and our findings were very similar to their data which showed only a small part of patients with insulinomas $(7 / 57,12 \%)$ had a slightly increased level of CgA (>100 ng/ml, the highest level: $164 \mathrm{ng} / \mathrm{ml}$ ). With a relatively low specificity (73\%), serum CgA was not a reliable and practicable biomarker for diagnosis of insulinoma. This finding is important. Some studies suggested that testing CgA levels should be mandatory for PNETs diagnosis [7]. Furthermore, according to recent North American Neuroendocrine Tumor Society (NANETS) and European Neuroendocrine Tumor Society (ENETS) consensus guidelines [28,29] as well as ESMO guidelines for NETs diagnosis [5], CgA was considered as a general biomarker for NETs, and CgA can be used as a marker in patients with both Functional PNET and NF-PNET $[28,29]$. Insulinoma is the most common subtype of functioning PNETs $[31,35,37,46]$. However, whether serum levels of CgA should be tested in patients with insulinomas has not been well clarified in those guidelines for NETs diagnosis. Our data and previous reports $[9,13]$ showed that insulinoma could be an exception for measuring serum levels of CgA for diagnostic purpose. It maybe not necessary to test CgA levels in patients with insulinomas although this issue needs to be further validated in more cases and in multiple clinical centers. In addition, using different commercial kits or assay could be useful to further validate our findings because the antibodies used in different assay were raised against the different domain or epitopes of the CgA molecular [12,15,17,47].

The underlying mechanism of low CgA levels in patients with insulinomas is not clear. Nobels et al. speculated the serum levels of CgA were only slightly elevated
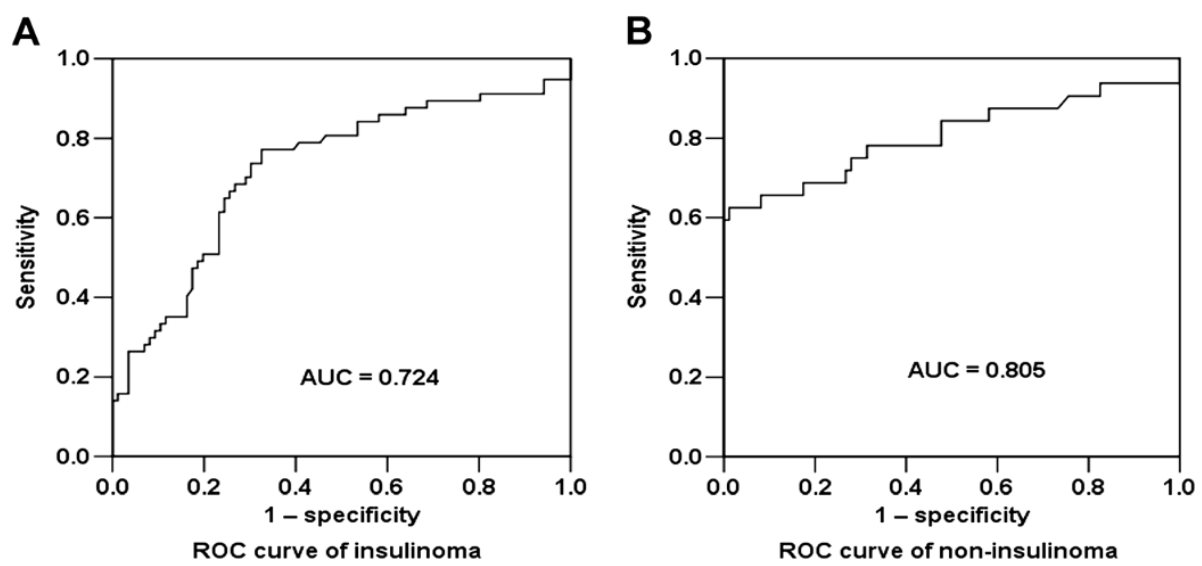

Figure 3 Diagnostic accuracy of CgA in PNETs. Figure $3 \mathbf{A}$ ROC curves of CgA levels in patients with insulinomas $(n=57)$ and in patients with non-insulinoma PNETs (Figure 3B, $n=32)$ versus healthy participants $(n=86)$. AUC: the area under the curve. 
Table 2 Correlation of CgA levels with clinicopathological features in patients with PNETs and insulinomas

\begin{tabular}{|c|c|c|c|}
\hline \multicolumn{2}{|c|}{$\begin{array}{l}\text { Clinicopathological features } \\
\text { of patients with PNETs }\end{array}$} & \multirow{2}{*}{$\begin{array}{l}\text { CgA levels (ng/ml) } \\
\text { median (range) } \\
67.9(46.1-9020.7)\end{array}$} & \multirow{2}{*}{$\begin{array}{l}\text { P value } \\
0.394\end{array}$} \\
\hline Gender & Male, $n=36$ & & \\
\hline & Female, $n=53$ & $67.2(25.0-4572.3)$ & \\
\hline \multirow[t]{2}{*}{ Age (years) } & $\leq 48, n=49$ & $64.8(25.0-5772.5)$ & 0.039 \\
\hline & $>48, n=38$ & $81.2(26.9-9020.7)$ & \\
\hline \multirow{2}{*}{$\begin{array}{l}\text { Primary tumor } \\
\text { location on pancreas }\end{array}$} & Head/neck, n = 41 & $62.5(25.0-5772.5)$ & 0.019 \\
\hline & Body/tail, $n=36$ & $81.9(45.7-9020.7)$ & \\
\hline \multirow[t]{2}{*}{ Tumor size (cm) } & $\mathrm{n}=82,0.8-8$ & $67.0(25.0-9020.7)$ & 0.545 \\
\hline & $r=0.068$ & & \\
\hline \multirow[t]{3}{*}{ Grade } & $\mathrm{G} 1, \mathrm{n}=37$ & $67.3(33.9-811.9)$ & 0.103 \\
\hline & $\mathrm{G} 2, \mathrm{n}=15$ & $74.3(26.9-1931.1)$ & \\
\hline & $\mathrm{G} 3, \mathrm{n}=2$ & $323.7(244.4-403.0)$ & \\
\hline \multirow[t]{4}{*}{ Stage } & $\mathrm{l}, \mathrm{n}=39$ & $67.2(25.0-137.2)$ & 0.003 \\
\hline & $\|, n=22$ & $61.6(51.2-241.7)$ & \\
\hline & $I I I, n=5$ & $244.4(26.9-811.9)$ & \\
\hline & $\mathrm{IV}, \mathrm{n}=18$ & $302.8(45.7-9020.7)$ & \\
\hline \multicolumn{2}{|c|}{$\begin{array}{l}\text { Clinicopathological features of } \\
\text { patients with insulinomas }\end{array}$} & $\begin{array}{l}\text { CgA levels }(\mathrm{ng} / \mathrm{ml}) \\
\text { median (range) }\end{array}$ & $P$ value \\
\hline \multirow[t]{2}{*}{ Gender } & Male, $n=25$ & $66.8(46.1-164.2)$ & 0.072 \\
\hline & Female, $n=32$ & $62.6(25.0-122.0)$ & \\
\hline \multirow[t]{2}{*}{ Age (years) } & $\leq 48, n=32$ & $61.4(25.0-164.2)$ & 0.003 \\
\hline & $>48, n=25$ & $73.3(51.2-137.2)$ & \\
\hline \multirow{4}{*}{$\begin{array}{l}\text { Primary tumor } \\
\text { location on pancreas }\end{array}$} & Head/neck & $61.9(25.0-122.0)$ & 0.009 \\
\hline & $n=30$ & & \\
\hline & Body/tail & $68.9(51.2-164.2)$ & \\
\hline & $n=26$ & & \\
\hline \multirow[t]{2}{*}{ Tumor size (cm) } & $n=56,0.8-4$ & $64.3(25.0-164.2)$ & 0.942 \\
\hline & $r=0.01$ & & \\
\hline \multirow[t]{2}{*}{ Grade } & $\mathrm{G} 1, \mathrm{n}=31$ & $64.8(33.9-164.2)$ & 0.795 \\
\hline & $G 2, n=4$ & $62.5(57.9-104.4)$ & \\
\hline \multirow[t]{2}{*}{ Stage } & Stage I, n = 39 & $67.2(25.0-137.2)$ & 0.215 \\
\hline & Stage $\|, n=15$ & $61.6(51.2-164.2)$ & \\
\hline
\end{tabular}

in subjects with small NETs, such as insulinomas, pituitary adenomas [9]. However, there is disagreement in the literatures whether the serum CgA levels correlate with the extent of NETs or size of these tumors $[7,21,32,48]$. In present study, we did not observe the correlation between the tumor size and CgA levels in PNETs $(P=0.545)$ and in insulinomas alone $(P=0.942)$. Some of non-insulinoma PNETs with relatively small size still had very high serum levels of $\mathrm{CgA}$, for example, $\mathrm{CgA}$ level was $4572 \mathrm{ng} / \mathrm{ml}$ in a gastrinoma of $1.5 \mathrm{~cm}$ in size, and the highest CgA level in present study was more than $9000 \mathrm{ng} / \mathrm{ml}$ in a glucagonoma of $2.5 \mathrm{~cm}$ in size.

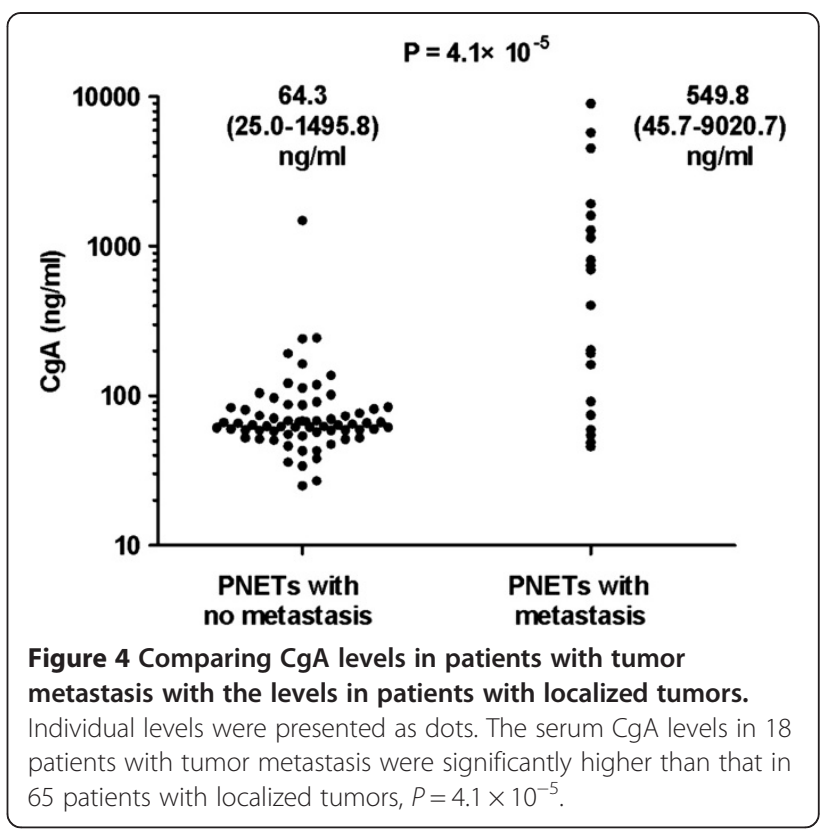

Furthermore, one patient with a NF of $3.5 \mathrm{~cm}$ in size had a CgA level of $5772 \mathrm{ng} / \mathrm{ml}$ whereas another patient with a NF of $8 \mathrm{~cm}$ in size had a CgA level of $59 \mathrm{ng} / \mathrm{ml}$.

Many previous studies $[10,13,15,41,42,49]$ and our present data showed that CgA levels in patients with NETs metastases were much higher than that in patients with localized NETs. Thus, it may hypothesized that few metastases in insulinomas would be the reason for low serum level of $\mathrm{CgA}$ in insulinomas (only one metastatic insulinoma in our serial). We found CgA levels in localized insulinomas were similar to that in localized non-insulinomas, $P=0.693$. This might imply the above hypothesis could be partly true. In fact, most of insulinomas $(>90 \%)$ are benign, absent metastasis in majority of insulinomas is one of the main characteristics of this unique tumor, and in our hospital, more than $95 \%$ of insulinomas are benign [37]. However, we noticed that the rate of elevated CgA levels in patients with localized non-insulinomas was significantly higher than that in patients with localized insulinomas, $P=0.015$. In addition, one report showed that in 9 of the 10 patients with gastrinoma, CgA values were raised, even in the absence of metastasis [41]. These data suggested that metastasis could be one of determinant factors for high levels of CgA in PNETs, but not the only one. The tumor subtype could be another important determinant for CgA serum levels. Nevertheless, more patients with metastatic insulinomas were needed to validate the low levels of CgA in insulinomas although it might be quite difficult to do so due to the limited numbers of malignant insulinomas.

It was reported that pancreastatin, a CgA-derived peptide (CgA residues 250-301) with biological activity, inhibited the releasing of insulin by islet beta cells $[7,50]$ 


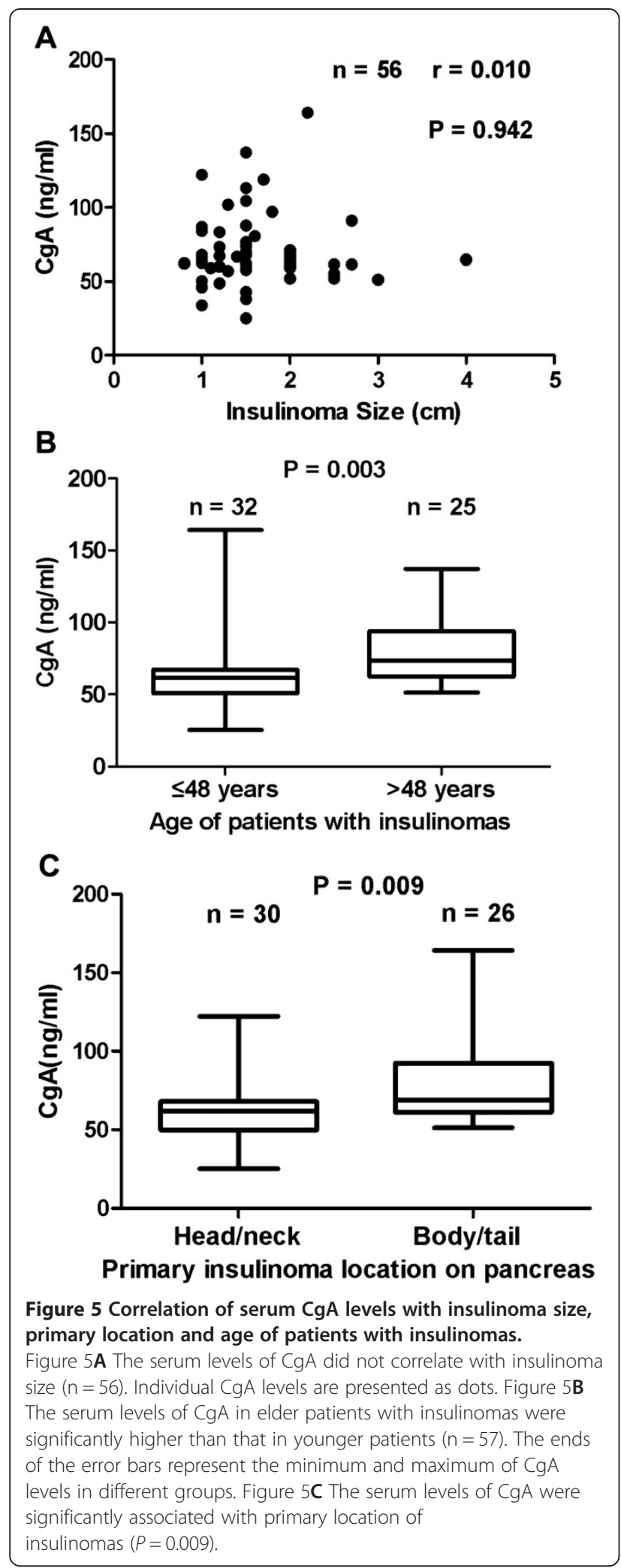

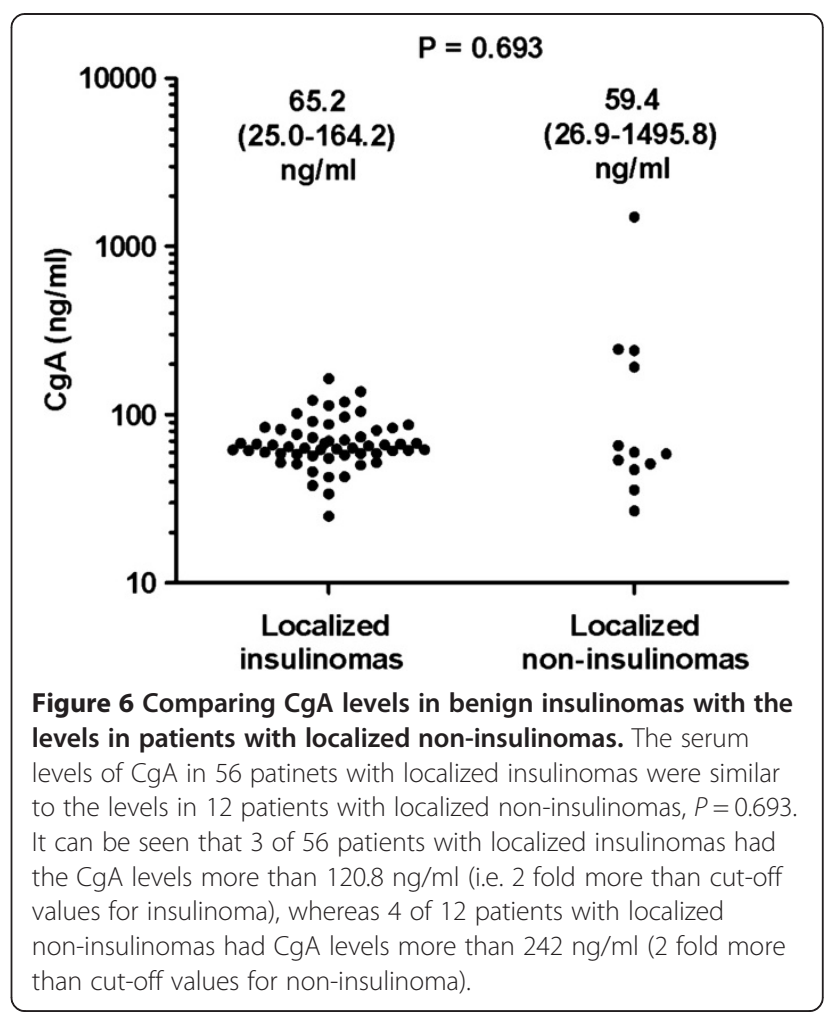

and insulinoma cell line [51]. Gayen et al. [52] observed an inverse relationship between pancreastatin and insulin. This CgA-derived peptide might antagonize the effect of insulin via the Akt/FOXO-1 and, administration of insulin could result in low plasma levels of pancreastatin in mice (the basal pancreastatin level dropped significantly following insulin injection). In majority of insulinomas, a great deal amount of insulin is secreted by tumor cells. We speculate that high levels of insulin in patients with insulinomas might inhibit the secretion of CgA in these tumor cells. A recent study demonstrated that insulin and proinsulin were released in patients with insulinomas in response to arterial calcium stimulation, whereas CgA was not released [53].

One research suggested that CgA targeted to secretory granules in association with protein secretogranin III, a member of granin family, in pituitary and pancreatic endocrine cells [54]. If other proteins such as secretogranin III were broken down, the secretion of CgA would be disrupted. The mechanisms of hormones and peptides secretion were very complicated, it maybe concerned with molecular cellular biology and the alterations of tumor cell functions.

Other than the low blood levels of CgA in insulinomas, the biomedical behaviors of insulinomas were quite different from other PNETs. For example, its low rate of malignancy $(<10 \%)$, the relatively low rate of positive Octreotide scintigraphy can be identified in benign insulinomas comparing with non-insulinoma PNETs because 


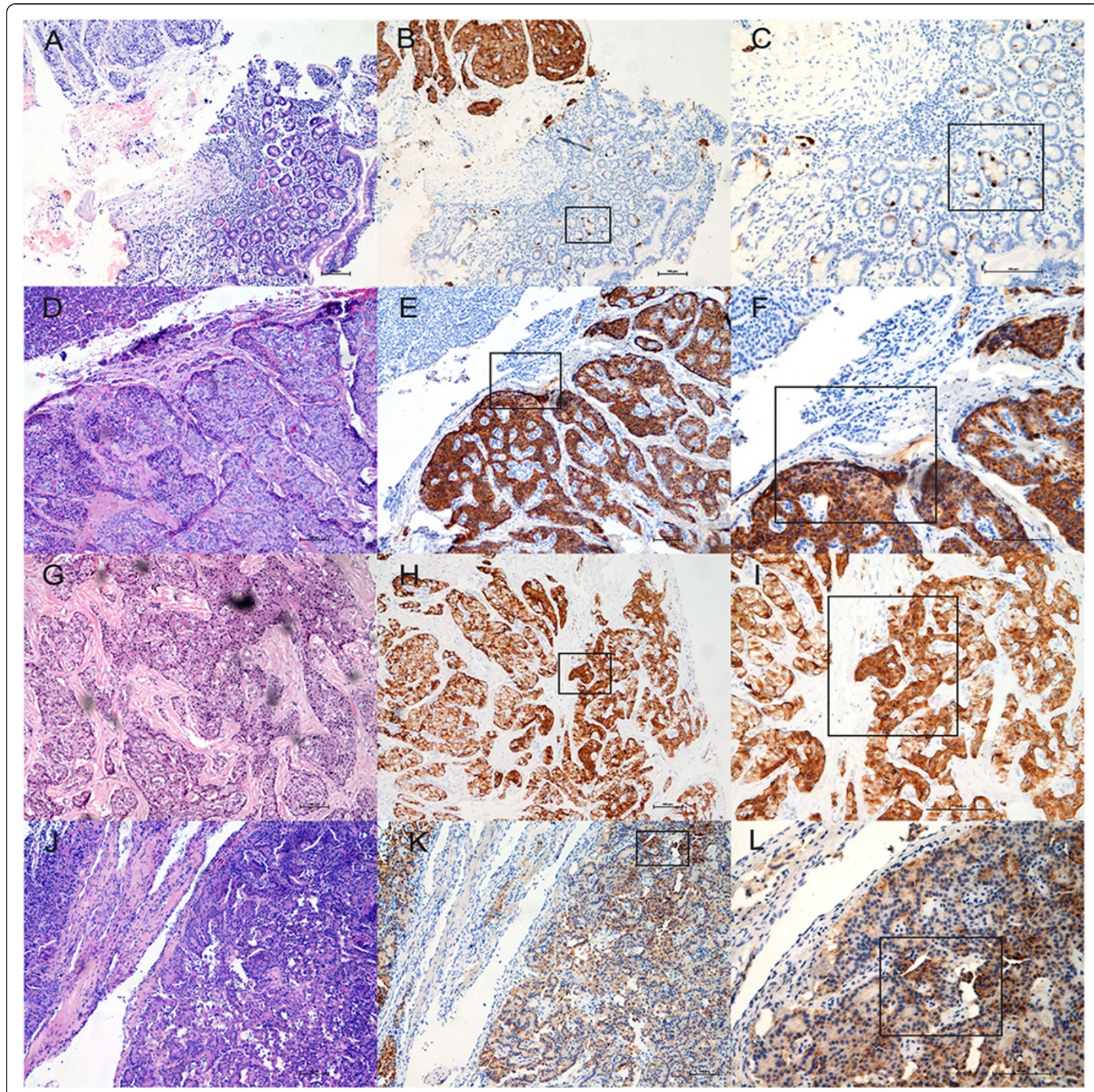

Figure 7 Representative examples of CgA expression in PNETs and their paired tissues. Left panel: HE staining; middle panel: CgA IHC, 10x; right panel: $\mathrm{CgA} \mathrm{IHC,} \mathrm{20x.} \mathrm{Figure} \mathrm{7A} \mathrm{shown} \mathrm{HE} \mathrm{staining} \mathrm{of} \mathrm{a} \mathrm{gastrinoma} \mathrm{located} \mathrm{in} \mathrm{duodenum,} \mathrm{Figure} 7 \mathbf{B}$ shown the strong expression of CgA protein in gastrinoma tissue and Figure $7 \mathbf{C}$ shown scattered $\mathrm{CgA}$ positive cells in non-tumoral duodenum tissue. Figure $7 \mathbf{D}$, Figure $7 \mathbf{G}$ and Figure 7J shown HE staining of 3 different insulinomas, respectively. Figure 7E-F, Figure $7 \mathbf{H}-\mathbf{I}$ and Figure $7 \mathbf{K}-\mathbf{L}$ shown the very strong signals of $\mathrm{CgA}$, strong signals of $\mathrm{CgA}$ and medium signals of $\mathrm{CgA}$ in 3 different insulinomas, respectively. In contrast, no expression of $\mathrm{CgA}$ can be seen in the interstitial tissues within the tumor and in the pancreatic exocrine tissues.

many insulinomas do not express somatostatin receptor subtypes [35]. All of these unusual features of insulinomas indicated that unique molecular cellular aspects and/or functions existed in insulinoma cells.

In this study, we have observed that most of insulinoma tissues (12/14) were shown strong positive staining for $\mathrm{CgA}$, indicating that insulinoma cells were able to synthesize the CgA protein. This aspect of insulinoma was similar to non-insulinoma PNETs. However, only small part of the protein might be secreted into blood by the insulinoma cells because the CgA levels were not elevated and, the CgA levels were significantly reduced in 16 patients after tumor resection (from median $64.8 \mathrm{ng} / \mathrm{ml}$ to median $50.4 \mathrm{ng} / \mathrm{ml}, P=0.003$ ). 
It is hard to explain why the serum level of CgA was postoperatively elevated in one patient who had normal liver and kidney functions. This patient did not suffer with other disease or take PPI or $\mathrm{H} 2$ receptor blocker. The sample was detected repeatedly and the same results were obtained.

In conclusion, our findings suggested that $\mathrm{CgA}$ is not a reliable biomarker for insulinomas, hence, examination of blood CgA levels could not be recommended in patients with insulinoms according to Nobels' [9] and our data. The mechanisms underlying low serum levels of $\mathrm{CgA}$ in insulinomas would appear to warrant further investigation.

\section{Conclusion}

The study revealed that the circulating CgA levels in patients with insulinomas were not obviously elevated, although we did validate the diagnostic value of serum CgA in a series of patients with non-insulinoma PNETs.

\section{Competing interests}

The authors declare that they have no conflict of interest.

\section{Authors' contributions}

YJC designed the study. XWQ, LQ, YJC, CTM, ZS, CMB, TPZ, YPZ, YHW and JC collected the samples and detected serum levels of CgA. XWQ, YJC, DCZ, YLS carried out the immunohistochemical staining. XWQ, LQ, CML and YJC analyzed the data and performed the statistical analysis. XWQ and YJC drafted the manuscript. All authors read and approved the final manuscript.

\section{Acknowledgement}

We thank Norvatis (China) Co. Ltd. for offering Chromogranin A ELISA kits.

\begin{abstract}
Author details
${ }^{1}$ Department of Gastroenterology, Peking Union Medical College Hospital, Peking Union Medical College, Chinese Academy of Medical Sciences, Beijing 100730, People's Republic of China. ²Department of Clinical Laboratory, Peking Union Medical College Hospital, Peking Union Medical College, Chinese Academy of Medical Sciences, Beijing 100730, People's Republic of China. ${ }^{3}$ Key Laboratory of Endocrinology (Ministry of Health), Department of Endocrinology, Peking Union Medical College Hospital, Peking Union Medical College, Chinese Academy of Medical Sciences, Beijing 100730, People's Republic of China. ${ }^{4}$ Department of Oncology, Peking Union Medical College Hospital, Peking Union Medical College, Chinese Academy of Medical Sciences, Beijing 100730, People's Republic of China. ${ }^{5}$ Department of Pathology, Peking Union Medical College Hospital, Peking Union Medical College, Chinese Academy of Medical Sciences, Beijing 100730, People's Republic of China. ${ }^{6}$ Department of Surgery, Peking Union Medical College Hospital, Peking Union Medical College, Chinese Academy of Medical Sciences, Beijing 100730, People's Republic of China. ${ }^{7}$ Department of Gastroenterology, The First Affiliated Hospital of Sun Yat-sen University, Guangzhou 510000, People's Republic of China.
\end{abstract}

Received: 18 February 2014 Accepted: 30 July 2014

Published: 7 August 2014

\section{References}

1. Rindi G, Wiedenmann B: Neuroendocrine neoplasms of the gut and pancreas: new insights. Nat Rev Endocrinol 2012, 8(1):54-64.

2. Yao JC, Hassan M, Phan A, Dagohoy C, Leary C, Mares JE, Abdalla EK, Fleming JB, Vauthey JN, Rashid A, Evans DB: One hundred years after "carcinoid": epidemiology of and prognostic factors for neuroendocrine tumors in 35,825 cases in the United States. J Clin Oncol 2008, 26(18):3063-3072.
3. Modlin IM, Oberg K, Chung DC, Jensen RT, de Herder WW, Thakker RV, Caplin M, Delle Fave G, Kaltsas GA, Krenning EP, Moss SF, Nilsson O, Rindi G, Salazar R, Ruszniewski P, Sundin A: Gastroenteropancreatic neuroendocrine tumours. Lancet Oncol 2008, 9(1):61-72.

4. Lawrence B, Gustafsson BI, Chan A, Svejda B, Kidd M, Modlin IM: The epidemiology of gastroenteropancreatic neuroendocrine tumors. Endocrinol Metab Clin North Am 2011, 40(1):1-18. vii.

5. Oberg K, Knigge U, Kwekkeboom D, Perren A, Group EGW: Neuroendocrine gastro-entero-pancreatic tumors: ESMO clinical practice guidelines for diagnosis, treatment and follow-up. Ann Oncol 2012, 23(Suppl 7):vii124-vii130.

6. Oberg K, Eriksson B: Endocrine tumours of the pancreas. Best Pract Res Clin Gastroenterol 2005, 19(5):753-781.

7. Modlin IM, Gustafsson BI, Moss SF, Pavel M, Tsolakis AV, Kidd M: Chromogranin A-biological function and clinical utility in neuro endocrine tumor disease. Ann Surg Oncol 2010, 17(9):2427-2443.

8. Singh S, Law C: Chromogranin A: a sensitive biomarker for the detection and post-treatment monitoring of gastroenteropancreatic neuroendocrine tumors. Expert Rev Gastroenterol Hepatol 2012, 6(3):313-334.

9. Nobels FR, Kwekkeboom DJ, Coopmans W, Schoenmakers CH, Lindemans J, De Herder WW, Krenning EP, Bouillon R, Lamberts SW: Chromogranin A as serum marker for neuroendocrine neoplasia: comparison with neuron-specific enolase and the alpha-subunit of glycoprotein hormones. J Clin Endocrinol Metab 1997, 82(8):2622-2628.

10. Bashir S, Gibril F, Ojeaburu JV, Asgharian B, Entsuah LK, Ferraro G, Crafa P, Bordi C, Jensen RT: Prospective study of the ability of histamine, serotonin or serum chromogranin A levels to identify gastric carcinoids in patients with gastrinomas. Aliment Pharmacol Ther 2002, 16(7):1367-1382.

11. Abou-Saif A, Gibril F, Ojeaburu JV, Bashir S, Entsuah LK, Asgharian B, Jensen RT: Prospective study of the ability of serial measurements of serum chromogranin A and gastrin to detect changes in tumor burden in patients with gastrinomas. Cancer 2003, 98(2):249-261.

12. Ardill JE, Erikkson B: The importance of the measurement of circulating markers in patients with neuroendocrine tumours of the pancreas and gut. Endocr Relat Cancer 2003, 10(4):459-462.

13. Nehar D, Lombard-Bohas C, Olivieri S, Claustrat B, Chayvialle JA, Penes MC, Sassolas G, Borson-Chazot F: Interest of Chromogranin A for diagnosis and follow-up of endocrine tumours. Clin Endocrinol (Oxf) 2004, 60(5):644-652.

14. Campana D, Nori F, Piscitelli L, Morselli-Labate AM, Pezzilli R, Corinaldesi R, Tomassetti P: Chromogranin A: is it a useful marker of neuroendocrine tumors? J Clin Oncol 2007, 25(15):1967-1973.

15. Zatelli MC, Torta M, Leon A, Ambrosio MR, Gion M, Tomassetti P, De Braud F, Delle Fave G, Dogliotti L, Degli Uberti EC, Italian CromaNet Working Group: Chromogranin A as a marker of neuroendocrine neoplasia: an Italian Multicenter Study. Endocr Relat Cancer 2007, 14(2):473-482.

16. Metz DC, Jensen RT: Gastrointestinal neuroendocrine tumors: pancreatic endocrine tumors. Gastroenterology 2008, 135(5):1469-1492.

17. Lawrence B, Gustafsson BI, Kidd M, Pavel M, Svejda B, Modlin IM: The clinical relevance of chromogranin $A$ as a biomarker for gastroenteropancreatic neuroendocrine tumors. Endocrinol Metab Clin North Am 2011, 40(1):111-134. viii.

18. Oberg K: Circulating biomarkers in gastroenteropancreatic neuroendocrine tumours. Endocr Relat Cancer 2011, 18(Suppl 1):S17-S25.

19. Chou WC, Hung YS, Hsu JT, Chen JS, Lu CH, Hwang TL, Rau KM, Yeh KY, Chen TC, Sun CF: Chromogranin A is a reliable biomarker for gastroenteropancreatic neuroendocrine tumors in an Asian population of patients. Neuroendocrinology 2012, 95(4):344-350.

20. Walter T, Chardon L, Chopin-laly X, Raverot V, Caffin AG, Chayvialle JA, Scoazec JY, Lombard-Bohas C: Is the combination of chromogranin A and pancreatic polypeptide serum determinations of interest in the diagnosis and follow-up of gastro-entero-pancreatic neuroendocrine tumours? Eur J Cancer 2012, 48(12):1766-1773.

21. Arnold R, Wilke A, Rinke A, Mayer C, Kann PH, Klose KJ, Scherag A, Hahmann M, Muller HH, Barth P: Plasma chromogranin A as marker for survival in patients with metastatic endocrine gastroenteropancreatic tumors. Clin Gastroenterol Hepatol 2008, 6(7):820-827.

22. Giovanella L, Marelli M, Ceriani L, Giardina G, Garancini S, Colombo L: Evaluation of chromogranin A expression in serum and tissues of breast cancer patients. Int J Biol Markers 2001, 16(4):268-272. 
23. Ranno S, Motta M, Rampello E, Risino C, Bennati E, Malaguarnera M: The chromogranin-A (CgA) in prostate cancer. Arch Gerontol Geriatr 2006 43(1):117-126

24. Sciarra A, Di Silverio F, Autran AM, Salciccia S, Gentilucci A, Alfarone A Gentile V: Distribution of high chromogranin A serum levels in patients with nonmetastatic and metastatic prostate adenocarcinoma. Urol Int 2009, 82(2):147-151.

25. Malaguarnera M, Vacante M, Fichera R, Cappellani A, Cristaldi E, Motta M: Chromogranin $\mathrm{A}(\mathrm{CgA})$ serum level as a marker of progression in hepatocellular carcinoma (HCC) of elderly patients. Arch Gerontol Geriatr 2010, 51(1):81-85.

26. Biondi A, Malaguarnera G, Vacante M, Berretta M, D'Agata V, Malaguarnera M, Basile F, Drago F, Bertino G: Elevated serum levels of Chromogranin A in hepatocellular carcinoma. BMC Surg 2012, 12(Suppl 1):S7.

27. Malaguarnera M, Cristaldi E, Cammalleri L, Colonna V, Lipari H, Capici A, Cavallaro A, Beretta M, Alessandria I, Luca S, Motta M: Elevated chromogranin $A(\mathrm{CgA})$ serum levels in the patients with advanced pancreatic cancer. Arch Gerontol Geriatr 2009, 48(2):213-217.

28. OToole D, Grossman A, Gross D, Delle Fave G, Barkmanova J, O'Connor J, Pape UF, Plockinger U, Mallorca Consensus Conference p, European Neuroendocrine Tumor S: ENETS consensus guidelines for the standards of care in neuroendocrine tumors: biochemical markers. Neuroendocrinology 2009, 90(2):194-202.

29. Vinik Al, Woltering EA, Warner RR, Caplin M, O'Dorisio TM, Wiseman GA, Coppola D, Go VL, North American Neuroendocrine Tumor S: NANETS consensus guidelines for the diagnosis of neuroendocrine tumor. Pancreas 2010, 39(6):713-734.

30. Grant CS: Insulinoma. Best Pract Res Clin Gastroenterol 2005, 19(5):783-798

31. Mathur A, Gorden P, Libutti SK: Insulinoma. Surg Clin North Am 2009, 89(5):1105-1121.

32. O'Dorisio TM, Krutzik SR, Woltering EA, Lindholm E, Joseph S, Gandolfi AE, Wang YZ, Boudreaux JP, Vinik Al, Go VL, Howe JR, Halfdanarson T, O'Dorisio MS, Mamikunian G: Development of a highly sensitive and specific carboxy-terminal human pancreastatin assay to monitor neuroendocrine tumor behavior. Pancreas 2010, 39(5):611-616.

33. Chen YJ, Vortmeyer A, Zhuang Z, Huang S, Jensen RT: Loss of heterozygosity of chromosome 1q in gastrinomas: occurrence and prognostic significance. Cancer Res 2003, 63(4):817-823.

34. Yang YM, Liu TH, Chen YJ, Jiang WJ, Qian JM, Lu X, Gao J, Wu SF, Sang XT, Chen J: Chromosome $1 \mathrm{q}$ loss of heterozygosity frequently occurs in sporadic insulinomas and is associated with tumor malignancy. Int J Cancer 2005, 117(2):234-240.

35. de Herder WW, Niederle B, Scoazec JY, Pauwels S, Kloppel G, Falconi M, Kwekkeboom DJ, Oberg K, Eriksson B, Wiedenmann B, Rindi G, O'Toole D, Ferone D, Frascati Consensus Conference, European Neuroendocrine Tumor Society: Well-differentiated pancreatic tumor/carcinoma: insulinoma. Neuroendocrinology 2006, 84(3):183-188.

36. Mei M, Deng D, Liu TH, Sang XT, Lu X, Xiang HD, Zhou J, Wu H, Yang Y, Chen J, Lu CM, Chen YJ: Clinical implications of microsatellite instability and MLH1 gene inactivation in sporadic insulinomas. J Clin Endocrinol Metab 2009, 94(9):3448-3457.

37. Zhao YP, Zhan HX, Zhang TP, Cong L, Dai MH, Liao Q, Cai LX: Surgical management of patients with insulinomas: Result of 292 cases in a single institution. J Surg Oncol 2011, 103(2):169-174.

38. Wang $Y H$, Lin $Y, X$ ue L, Wang $J H$, Chen MH, Chen J: Relationship between clinical characteristics and survival of gastroenteropancreatic neuroendocrine neoplasms: A single-institution analysis (1995-2012) in South China. BMC Endocr Disord 2012, 12:30

39. Liu B, Tang LH, Liu Z, Mei M, Yu R, Dhall D, Qiao XW, Zhang TP, Zhao YP, Liu TH, Xiao Y, Chen J, Xiang HD, Wu HY, Lu CM, LV B, Zhou YR, Zhang Y, Deng DJ, Chen YJ: Alpha-Internexin: a novel biomarker for pancreatic neuroendocrine tumor aggressiveness. J Clin Endocrinol Metab 2014, 99(5):E786-E795.

40. Rindi G, Falconi M, Klersy C, Albarello L, Boninsegna L, Buchler MW, Capella C, Caplin M, Couvelard A, Doglioni C, Delle Fave G, Fischer L, Fusai G, de Herder WW, Jann H, Komminoth P, de Krijger RR, La Rosa S, Luong TV, Pape U, Perren A, Ruszniewski P, Scarpa A, Schmitt A, Solcia E, Wiedenmann B: TNM staging of neoplasms of the endocrine pancreas: results from a large international cohort study. J Natl Cancer Inst 2012, 104(10):764-777.
41. Tomassetti $P$, Migliori M, Simoni $P$, Casadei $R$, De lasio R, Corinaldesi $R$, Gullo L: Diagnostic value of plasma chromogranin A in neuroendocrine tumours. Eur J Gastroenterol Hepatol 2001, 13(1):55-58.

42. Paik WH, Ryu JK, Song BJ, Kim J, Park JK, Kim YT, Yoon YB: Clinical usefulness of plasma chromogranin a in pancreatic neuroendocrine neoplasm. J Korean Med Sci 2013, 28(5):750-754

43. de Herder WW: Biochemistry of neuroendocrine tumours. Best Pract Res Clin Endocrinol Metab 2007, 21(1):33-41.

44. Portela-Gomes GM, Grimelius L, Wilander E, Stridsberg M: Granins and granin-related peptides in neuroendocrine tumours. Regul Pept 2010, 165(1):12-20.

45. Ramage JK, Ahmed A, Ardill J, Bax N, Breen DJ, Caplin ME, Corrie P, Davar J, Davies AH, Lewington V, Meyer T, Newell-Price J, Poston G, Reed N, Rockall A, Steward W, Thakker RV, Toubanakis C, Valle J, Verbeke C, Grossman AB, Uk Ireland Neuroendocrine Tumour Society: Guidelines for the management of gastroenteropancreatic neuroendocrine (including carcinoid) tumours (NETs). Gut 2012, 61(1):6-32.

46. Crippa S, Zerbi A, Boninsegna L, Capitanio V, Partelli S, Balzano G, Pederzoli P, Di Carlo V, Falconi M: Surgical management of insulinomas: short- and long-term outcomes after enucleations and pancreatic resections. Arch Surg 2012, 147(3):261-266.

47. Molina R, Alvarez E, Aniel-Quiroga A, Borque M, Candas B, Leon A, Poyatos RM, Gelabert M: Evaluation of chromogranin A determined by three different procedures in patients with benign diseases, neuroendocrine tumors and other malignancies. Tumour Biol 2011, 32(1):13-22.

48. Ito $T$, Igarashi $H$, Jensen RT: Serum pancreastatin: the long sought universal, sensitive, specific tumor marker for neuroendocrine tumors? Pancreas 2012, 41(4):505-507.

49. Nolting $S$, Kuttner A, Lauseker M, Vogeser M, Haug A, Herrmann KA, Hoffmann JN, Spitzweg C, Goke B, Auernhammer CJ: Chromogranin a as serum marker for gastroenteropancreatic neuroendocrine tumors: a single center experience and literature review. Cancers 2012, 4(1):141-155.

50. Tatemoto K, Efendic S, Mutt V, Makk G, Feistner GJ, Barchas JD: Pancreastatin, a novel pancreatic peptide that inhibits insulin secretion. Nature 1986, 324(6096):476-478.

51. Hertelendy Zl, Patel DG, Knittel JJ: Pancreastatin inhibits insulin secretion in RINm5F cells through obstruction of G-protein mediated, calciumdirected exocytosis. Cell Calcium 1996, 19(2):125-132.

52. Gayen JR, Saberi M, Schenk S, Biswas N, Vaingankar SM, Cheung WW, Najjar SM, O'Connor DT, Bandyopadhyay G, Mahata SK: A novel pathway of insulin sensitivity in chromogranin A null mice: a crucial role for pancreastatin in glucose homeostasis. J Biol Chem 2009, 284(42):28498-28509.

53. Wiesli $P$, Uthoff $H$, Perren A, Pfammatter $T$, Zwimpfer $C$, Seiler $H$, Kindhauser $R$, Spinas GA, Schmid C: Are biochemical markers of neuroendocrine tumors coreleased with insulin following local calcium stimulation in patients with insulinomas? Pancreas 2011, 40(7):995-999.

54. Hosaka M, Watanabe T, Sakai Y, Uchiyama Y, Takeuchi T: Identification of a chromogranin A domain that mediates binding to secretogranin III and targeting to secretory granules in pituitary cells and pancreatic beta-cells. Mol Biol Cell 2002, 13(10):3388-3399.

\section{doi:10.1186/1472-6823-14-64}

Cite this article as: Qiao et al:: Chromogranin A is a reliable serum diagnostic biomarker for pancreatic neuroendocrine tumors but not for insulinomas. BMC Endocrine Disorders 2014 14:64. 